\title{
THE PUBLICISATION OF PRIVATE RELATIONS BY HORIZONTAL APPLICATION OF CONSTITUTIONAL RIGHTS:
}

\begin{abstract}
Constitutional courts (CCs) are more and more often facing a situation in which the status of entities of legal relation escapes public - private distinction. The reasons for this include inter alia the privatization of state tasks. To ensure the efficiency of fundamental rights in a "reduced" state, CCs develop instruments that make it possible to apply constitutional provisions also in formally private relations. These instruments are based on the horizontal application of constitutional rights. They result in the publicisation of private relations. The measures taken by CCs restore the balance previously disturbed because of privatization. Therefore I describe them as a "return" or "corrective" publicisation. Despite important differences between legal cultures and the legal reality in particular countries (Germany, USA, Poland) the mechanism of judicial publicisation is based, to some extent, on universal argumentation.
\end{abstract}

* Assistant professor at the Department of Constitutional Law at the Faculty of Law and Administration of the Nicolaus Copernicus University. A principal investigator of the individual grant financed by the National Science Centre „Drittwirkung der Grundrechte as a legal concept. The German experience and recommendations for Poland". A member of the The International Society of Public Law (ICON S). ORCID 0000-0001-9422-0992; e-mail: i_wroblewska@law.umk.pl.

** This article is a written, substantially extended version of the paper delivered at the ICON-S conference held in Santiago de Chile from July 1 to July 3, 2019. The article was prepared within the framework of the research project entitled "Drittwirkung der Grundrechte as a legal concept. The German experience and recommendations for Poland" financed by the National Science Centre (2014/15/B/HS5/03190). 


\section{Keywords}

horizontal - application of constitutional rights - publicisation of private relations, constitutional courts - privatization of states tasks

\section{INTRODUCTION: PUBLIC-PRIVATE}

The question of the division into public and private law, which was present in ancient philosophy, but lost its importance in the Middle Ages, has been an important and constant subject of academic reflection all over the world since the advent of modern times. The existence of public law that is distinct from private law, understood as a set of specific rules applied in administration, is present in all legal systems, but nevertheless, according to M. Lemmonier, this distinction is a way of thinking about the law which has not been established everywhere and always in the same way ${ }^{1}$. First of all, it must be remembered that there is a difference between the states of civil and common law, because in the latter, the division in question is not very explicit and the norms of public and private law do not form separate systems ${ }^{2}$. However, they include institutions or rules of public law that differ from those applied in the private law order, such as public rights in the United States, which relate to the exercise of constitutional functions by the legislature or the executive ${ }^{3}$. Although many other criterium divisionis ${ }^{4}$ have been formulated, starting with

${ }^{1}$ M. Lemmonier, Prawo publiczne a prawo prywatne. Uwagi prawnoporównawcze na podstawie prawa francuskiego, [Public law and private law. Comparative legal remarks based on French law], “Studia Prawno-Ekonomiczne”, v. C, 2016, pp. 68-69, [last accessed: 31.07.2019].

2 Opinions critical of the legitimacy and need for a division into public and private law present in the science of law in the United Kingdom and the USA are presented by A. Clapham in Human Rights in the Private Sphere, Oxford 1993, pp. 130-133 and 150-151.

${ }^{3}$ E. Zoller, Introduction au droit public [Introduction to Public Law], "Dalloz" No 1-2, 2006, as cited in: “Revue de Droit Henri Capitant", No 30, Lexbase, 2012, p. I, as cited in: Lemmonier, supra note 1 at p. 71.

${ }^{4}$ Cf. on this subject e.g. J. Holliger, Das Kriterium des Gegensatzes zwischen dem öffentlichen Recht und dem Privatrecht dargestellt im Prinzipe und in einigen Anwendungen mit besonderer Berücksichtigung des schweizerischen Rechtes [The criterion of the opposition between public law and private law presented in principle and in some applications with particular 
the ancient Ulpianian utilitas, there is no consensus on the elementary question of whether this dichotomy stems from the very nature of law, and therefore has cognitive significance, or whether it is a question of adopting criteria that are external to law, and thus results from a specific convention, ideology, or value, and the boundary of separation is not clear or certain 5 .

Notwithstanding the existing difficulties in separating the two spheres, or even in assuming that any dividing criteria must, in principle, be indicative, there is agreement as regards the classification, according to which constitutional, criminal, or administrative law are types of public law, and civil law is primarily private law. The key issue here is to distinguish the sphere in which the individual is subject to the authority of state bodies in the sense of public intervention in their functioning, from the sphere that is free from $i t^{6}$, in which the individual shapes his or her behaviour on the basis of private autonomy.

The existence of private autonomy and the related possibility of creating one's own affairs with all parties having equal status is considered to be the feature that characterizes horizontal relations most accurately. However, the systems of law undergo transformations that affect the possibility of easily separating the private sphere from the public sphere. The most diverse aspects of these transformations have long been analysed in the academic literature ${ }^{7}$. Particular attention is drawn to the progression of publicising the entire law, which is manifested by the growing interference of the public factor in the domain that had previously been reserved for the autonomous behaviour of

reference to Swiss law], Zürich 1904, p. 11; J. Nowacki, Prawo publiczne - prawo prywatne [Public Law - Private Law], Katowice 1992, pp. 70-105.

${ }^{5}$ More on the subject Nowacki, supra note 4 at p. 132.

${ }^{6}$ L. Morawski, Wstęp do prawoznawstwa [Introduction to jurisprudence], Torun 2005, pp. 90-91.

7 See e.g. J. Habermas, Strukturwandel der Öffentlichkeit: Untersuchungen zu einer Kategorie der bürgerlichen Gesellschaft [The Structural Transformation of the Public Sphere: An Inquiry into a Category of Bourgeois Society], Frankfurt 1962; M. Ruffert (ed.), The Public Private Law Divide: Potential for Transformation?, London 2009; M.R. Freedland, J.-B. Auby (eds), The Public Law/Private Law Divide. Une entente assez cordiale? (Studies of the Oxford Institute of European E Comparative Law), Hart Publishing, 2006. 
individuals ${ }^{8}$. It leads to a significant limitation of the sphere that is free from public interference. This transformation is most visible from the perspective of civil law, because, as it is observed, its essence is to depart from the classic assumptions of the nineteenth-century codification ${ }^{9}$. Thus, we are dealing primarily with limiting the field of application of the private law method in favour of public law regulations, i.e. the exclusion of certain segments from the scope of private law and the increasingly distinctive infiltration of the collective interest in the area of relations left on the basis of traditional exclusivity of the parties ${ }^{10}$. We will return to more detailed manifestations of publicising the law later in the text, and at this juncture we will only note that in principle it is perceived as a threat to individual freedom which cannot be reconciled with the ideology of human rights. Meanwhile, the expansion of the function of modern states, which is the main reason for publicising the law ${ }^{11}$, is connected with the idea of securing constitutional regulations that guarantee rights and freedoms by state authorities. Moreover, such action by the state could be justified even from the perspective of classical liberalism, which allowed it to intervene if its aim was to maintain proper relations between citizens ${ }^{12}$. As early as in the mid-19 ${ }^{\text {th }}$ century, it was observed that the state should interfere with private law relations in order to protect their weaker side ${ }^{13}$. The expansion of state interventionism in the second half of the twentieth century was justified by the realisation of the growing scope of social functions. Above all, however, it should be stressed that it was the increase in the importance of the constitution and its guaranteeing function that significantly limited the autonomy of

${ }^{8}$ M. Safjan, Pojeccie i systematyka prawa prywatnego [The notion and the organisation of private law], [in:] M. Safjan (ed.), System prawa prywatnego [The system of private law]. Vol. 1. Prawo cywilne - część ogólna [Civil law - general part], Warsaw: C.H. Beck 2012, p. 49.

${ }^{9}$ Ibid, p. 49.

${ }^{10}$ Ibid., p. 50.

${ }^{11}$ L. Morawski, supra note 6 at p. 93. The development of technology is also significant. A separate issue, however, is the emergence of totalitarian regimes with their philosophy which asserts that everything is a public matter. Cf. J. Nowacki, supra note 4 at pp. 108-109.

${ }_{12} \mathrm{H}$. Spencer, The man versus the state: with six essays on government, society, and freedom, Indianapolis 1981, p. 127.

13 J. Limbach, "Promieniowanie" konstytucji na prawo prywatne ["Radiation" of the constitution onto private law], „Kwartalnik Prawa Prywatnego” no. 3/1999, p. 407. 
private law in relation to the constitutional system of values, including values that express human rights. Following the jurisprudence of the Federal Constitutional Court, the German legal doctrine in this context speaks of the double binding nature of fundamental rights. As part of constitutional law, they are classic public-private norms used in vertical relations. At the same time, being the core of the objective order of values (objektive Werteordnung), they affect the entire legal system in such a way that no provision - including private law - can be in conflict with this order $^{14}$.

\section{CONStitutional Rights IN A "REDUCED STATE"}

The publicisation of private law is a complex and internally heterogeneous phenomenon. The activities of the legislator, who introduces public regulations into the private sphere, are of fundamental importance. As a result, mixed areas emerge which are not subject to clear characteristics, the most evident example of which is labour law. The diversification of the scope and intensity of the state's interference in these relations is the response of the legislator to the diversity of legal relations occurring on the grounds of exchanging goods and services. A greater number of mandatory standards protecting the weaker side of legal relations in consumer trade (unilaterally professional) is the result of the observation that it differs significantly from the general and bilaterally professional trade, where the position of the parties is relatively equal and the iuris dispositivi regulation is sufficient.

The subject of interest of this article is the publicisation of private law which is observed in jurisprudence. More precisely, it refers to the situations in which a horizontal application of constitutional rights and freedoms in specific decisions is a response to the privatisation of the tasks and functions of the state. The jurisprudence strategies presented below, which make possible the protection of the rights of individuals in the conditions of the 'reduction of the state' have been developed in the decisions of the Federal Constitutional Court of Germany and the

${ }^{14}$ Judgment of 15 January 1958, 1 BvR 400/51, BVerfGE 7, 198 - Lüth. 
Supreme Court of the United States. When justifying this choice, it should be noted that these are the longest-established concepts with the widest scope of influence ${ }^{15}$. It is possible that these strategies have a direct impact on the decisions of courts in other countries, and that they may be used as a model or a point of reference when creating domestic solutions in this scope ${ }^{16}$. In this text a national perspective on the protection of 'constitutional rights' in private relations has been adopted, although it is of course a problem that has been present for many decades at the level of the international protection of human rights. The latter perspective focuses in particular on the issue of globalisation, which, by leading to the development of transnational private corporations, drastically diverges from the ideals of human rights ${ }^{17}$.

It can be assumed, by the use of a certain simplification, that publicising private law is the reverse of privatising public law. Speaking of

15 Interestingly, K. Stern, when speaking about the progenitors of German debates on Drittwirkung, points to the United States and the jurisprudence of the Supreme Court, which, at the same time as developing the state action doctrine, issued many decisions maintained in the spirit of the horizontal effect of fundamental rights. See. G. Thüsing, Die "Drittwirkung der Grundrechte" im Verfassungsrecht der Vereinigten Staaten [The "thirdparty effect of fundamental rights" in the constitutional law of the United States], "Zeitschrift für Vergleichende Rechtswissenschaft" 2000, Bd. 99, p. 70.

${ }^{16}$ The question of influence is a separate and extremely broad issue, broached in many publications particularly in the context of Drittwirkung (see e.g. articles presented in: A. Sajo, R. Uitz (eds), The Constitution in Private Relations: Expanding Constitutionalism, Utrecht 2005). By way of illustration let us only mention the judgment of the Constitutional Court of South Africa of 15 May 1996 in the Du Plessis v. De Klerk case, which referred extensively to the German concept of horizontality in its content (see e.g. J. Van der Walt, Drittwirkung in Südafrika und Deutschland: Ein Forschungsbericht [Drittwirkung in South Africa and Germany: A research report], „Die Öffentliche Verwaltung” 19/2001, 805-814). As regards the constitutional solutions that consist in the adoption of a general horizontal clause, they have been applied in Greece (Article 25 (1) (3) of the 1975 Constitution in its 2001 version), Portugal (Article 18(1) of the 1976 Constitution in its 1997 version), and South Africa (Article 8(2) of the 1996 Constitution).

17 This issue has received extensive coverage in the literature around the world. See e.g. N. McMurry, Water privatisation: Diminished Accountability, "5 Hum. Rts. \& Int'1 Legal Discourse“ Vol. 5, no 2, 2011 pp. 233-263; A. McBeth, Privatising Human Rights: What Happens to the State's Human Rights Duties When Services are Privatised?, "Melbourne Journal of International Law" 5(1), 2004, http://classic.austlii.edu.au/au/journals/ MelbJIL/2004/5.html [last accessed 31.07.2019]. 
privatisation, I mean situations in which the state either delegates its tasks or functions ${ }^{18}$, or uses private-law forms of action. More precisely, A. McBeth distinguishes between 'privatisation' and 'contracting out'. The former phenomenon refers to a situation whereby a previously staterun service is transferred to non-state operation. The latter, as subset of privatisation, encompasses the cases where ownership of the service enterprise remains with the state, but the provision of the service is transferred to non-state entities on a contractual basis ${ }^{19}$. Privatisation of areas once considered to be the domain of the state, such as public security, education, energy, health care, or the penitentiary system, is becoming increasingly widespread ${ }^{20}$. In consequence of the private and public spheres mutually penetrating each other, courts as well as other bodies applying the law are increasingly deciding on cases in which the status of entities in a legal relationship eludes public-private distinction. Delegation of public duties to the private sphere results in equipping a certain group of private entities with attributes that, according to classical criteria, characterize public-private participants in legal transactions. Having administrative power or a monopoly position in the scope of performed tasks (services provided), they acquire the ability to unilaterally shape the legal situation (rights and obligations) of an individual-consumer. In such a formal private-law relation, its essence, i.e. equality and autonomy of parties, is banished. The weakening of the position of an individual-consumer in simplified terms consists in the fact that if privatisation had not taken place and the given task, function or service was still performed by the state, the individual would benefit

${ }_{18}$ In view of the fact that in the countries whose experience will be mentioned below, both the concept of a task (Federal Republic of Germany) and that of a function (USA) are present in the context of privatisation, in these remarks the precise delineation of these concepts has been abandoned. More specifically, it should be assumed that 'function' is essentially a broader concept, similar to the concept of purpose, whereas tasks are performed in the performance of functions.

${ }_{19}$ McBeth, supra note 17 in point IV.

${ }^{20}$ In the most developed countries, economic balance has long determined their abandonment of many of the traditional attributes of state functions, and what is more, in some of them, in the USA for example, the largest industrial corporations are historically private. 
from the protection of their rights and freedoms guaranteed by the norms of the Constitution on the basis of their direct vertical action. However, in a situation where the status of entities in a legal relation eludes publicprivate distinction, it is not clear whether and how they can be held liable under these norms. It seems that the argumentative similarity observable in the judgments cited later in the text allows us to speak of a certain universality, and in a broader perspective than only the perspective of the presented countries. After all, we are talking about different countries that have completely different legal systems and cultures. The universality of court strategies is primarily the result of the fact that the phenomenon of the constitutionalisation of legal systems is strengthening. Another important factor is the "permeation" of the contemporary legal culture with the philosophy of human rights, expressed in an extensive catalogue of international and European legal acts. For example, according to the Preamble to the Universal Declaration of Human Rights, the aim of this document is that "all peoples and every organ of society shall strive ... to secure their universal and effective recognition and observance". In international systems, it is generally accepted that only the state can violate Convention rights, but even here a concept has been developed which extends their effectiveness to horizontal relations. The concept of State protection obligations, which has existed for several decades in the jurisprudence of the European Court of Human Rights and the InterAmerican Court of Human Rights ${ }^{21}$, has created the possibility of the challenging of an infringement of Convention rights by a private entity on condition that the infringement is linked to an act or omission by the State $^{22}$. This gives rise to the liability of the State, which, as a party to the Convention, is obliged to protect one private party against infringements of its rights by another private party.

${ }^{21}$ This concept was first formulated in the judgment of the ECHR of 23 July 1968, Belgian Linguistic Case and the judgment of the ECHR of 29 July 1988, Velasquez Rodriguez v. Honduras Case.

${ }^{22}$ L. Garlicki, Relations between Private Actors and the European Convention on Human Rights, [in:] Sajo, Uitz, supra note 16, at p. 130. 


\section{JUDICIAL STRATEGIES TOWARDS THE STATE'S ESCAPE INTO PRIVATE LAW}

The common denominator of the analysed decisions in cases where one private entity demands protection of its constitutional rights in relation to the other, formally private entity, is the statement that "the change of the role of the State from a guarantor to a service provider does not abolish the binding nature of constitutional rights ${ }^{23}$. In other words, the state cannot "contract out" the responsibility for constitutional obligations through the so-called "escape into private law". This latter formulation expresses the intentional character of the activities of contemporary states, which, when deciding on a private form of a given activity are guided not so much by economic criteria as by the desire to get rid of specific public tasks in order not to be responsible for them ${ }^{24}$.

Thus, in modern society, constitutional rights and freedoms may be threatened both by the state and by those private economic entities which, by assuming public responsibilities, gain significant dominance over the entities to which these responsibilities are provided. Their advantage is significantly strengthened by the fact that, not being subject to the obligation to act in the public interest, they are usually guided only by simple profit and loss motives. As we know, constitutional rights and freedoms do not, as a rule, apply directly to relations between private entities. However, most legal orders have developed ways and techniques of providing for a certain degree of the influence that fundamental rights have on private relationship ${ }^{25}$. Nowadays, there is no doubt that "the more the horizontal relationship becomes similar to the vertical relationship, the more justified is state interference aimed at protecting the constitutional

${ }^{23}$ McBeth, supra note 17 in the footnote 1.

${ }^{24}$ Such an intention of privatisation activities is observed in America\{n?\} (D. Barack, A State Action Doctrine for an Age of Privatization, "Syracuse Law Review", Vol. 45, 1995, p. 1170 et seq.), German (J. Masing, Grundrechtsschutz trotz Privatisierung, [in:] M. Bäuerle, Ph. Dann, A. Wallrabenstein, Demokratie-Perspektiven, Festschrift für Brun-Otto Bryde zum 70. Geburtstag, Mohr Siebeck 2013, passim), and the Polish literature (E. Łętowska, Prawo w "płynnej nowoczesności" [Law in "fluid modernity"], "Państwo i Prawo" 3/2014, p. 23).

${ }^{25}$ G. Sommeregger, The Horizontalization of Equality: the German Attempt to Promote Non-Discrimination in the Private Sphere via Legislation, [in:] Sajo, Uitz, supra note 16 at p. 41. 
rights of the weaker party in that relationship" ${ }^{26}$. If statutory regulations are unable to provide an adequate level of protection, which is particularly the case where the delegation of tasks by the state administration serves to relinquish responsibility for their performance, then what remains is the court's interference in a specific case. The development of jurisprudence instruments and strategies to ensure the effectiveness of fundamental rights in private relations takes place primarily in the jurisprudence of constitutional courts. The question of the reasons for their rather restrained application in the jurisprudence of courts of law, which is particularly important in the case of the States belonging to the European civil law circle ${ }^{27}$, goes beyond the scope of this Article, since it is a wider problem arising from the understanding of the meaning and role of the Constitution in the legal system. It can only be noted that it is undoubtedly linked to the attachment in those States to the traditional division between public and private law. However, it is no secret that the control of court judgments as regards the fulfilment of constitutional provisions on rights and freedoms is carried out by constitutional courts or higher instance courts when reference is made to these schemes. Awareness of this fact is undoubtedly a motivating factor behind reaching for a horizontal interpretation of the Constitution.

As mentioned above, the strategies based on two concepts: German Drittwirkung ${ }^{28}$ and American state action are the most characteristic and well-known. Despite the fundamental differences in the underlying philosophy and the different pattern of their application, as will be discussed below, they are usually presented as equivalent because of their identical objective of safeguarding the rights of the individual ${ }^{29}$.

${ }^{26}$ M. Florczak-Wątor, Horyzontalny wymiar praw konstytucyjnych, [Horizontal dimension of constitutional rights] Kraków 2014, p. 60.

27 Z. Kühn, "Making Constitutionalism Horizontal: Three Different Central European Strategies", [in:] Sajo. Uitz, supra note 16 at pp. 217-240.

${ }^{28}$ On the subject in English see e.g. K.M. Lewan, The Significance of Constitutional Rights for Private Law: Theory and Practice in West Germany, "International and Comparative Law Quarterly, 17/1968, pp. 571-601; U. Preuss, The German Drittwirkung Doctrine and Its Socio-Political Background, [in:] Sajo, Uitz, supra note 16 at pp. 23-32.

${ }^{29}$ Cf. e.g. M. Tushnet, The Relationship between Judicial Review of Legislation and the Interpretation of Non-Constitutional Law, with Reference to third Party Effect, [in:] Sajo, Uitz, supra note 16 at p. 167. 
Of course, behind each of these concepts there is a line of jurisprudence developed over many decades, referring to more detailed variants within the framework of different factual states.

The first strategy boils down to taking into account fundamental rights in the process of interpreting and applying the law, in accordance with the principle developed in the jurisprudence of the Federal Constitutional Court that "the objective values of the Basic Law affect all areas of law, including private law" ${ }^{\prime 30}$. This impact of constitutional norms is referred to as 'radiation' (Ausstrahlungswirkung). In such a case, the horizontal effect is indirect, since it does not create constitutional obligations on the part of private entities. Rather, as M. Sommeregger explains, "fundamental rights pass by the screen of private law before they reach the individual" ${ }^{31}$. The approach inspired by the German construct, unlike the US state action concept, is referred to as substance-oriented because it consists in assuring the compatibility of substantive legal rules with the constitution ${ }^{32}$. A manifestation of the publicising private law here is the obligation to take into account the material primacy of the constitutional norms expressing fundamental rights. It can be linked to Article 1(3) of the Basic Law, which directly obliges all holders of public power, and therefore also courts, to take into account the importance of these rights within the whole system of law. In view of the Federal Constitutional Court, this implies an obligation to interpret the law, including private law 'in the light of fundamental rights'. The statement of the Federal Constitutional Court in the constitutional complaint procedure that a civil court judgment did not take into account the importance of a fundamental right results in its annulment. The German concept of Drittwirkung, therefore, allows for a relatively broad publicising effect, but it is partial ${ }^{33}$ since it does not impose direct constitutional obligations on private entities. ${ }^{34}$

${ }^{30}$ Lüth-decision, supra note 14 .

${ }^{31}$ Sommeregger, supra note 25 at p. 43.

${ }^{32}$ R. Uitz, Yet Another Revival of Horizontal Effect of Constitutional Rights: Why? And Why Now? - an Introduction, [in:] Sajo, Uitz, supra note 16 at p. 7.

${ }^{33}$ Similarly P.E. Quint, Free Speech and Private Law in German Constitutional Theory, “Maryland Law Review", Vol. 48, 1989, p. 266, https:/ / digitalcommons.law.umaryland. $\mathrm{edu} / \mathrm{mlr} / \mathrm{vol} 48 /$ iss2/3/ [last accessed 31.07.2019].

34 The interpretation of Drittwirkung in the spirit of direct (absolute) horizontality, which was applicable in the first years after the entry into force of the German Basic 
Placing the state action doctrine among the models of the horizontal action of rights and freedoms requires certain explanations, because in the light of the interpretation of the US Constitution, its provisions, apart from the prohibition of slavery in the $13^{\text {th }}$ Amendment, apply only to vertical relations ${ }^{35}$. On the other hand, the horizontal effect can be de facto allowed exactly on the basis of the state action doctrine, and what is more, if it happens, it takes on a direct form ${ }^{36}$ - and this is the specificity of the American approach to this issue. When a private action is classified as state action, the same tools are used to assess it as the tools to assess the state action. However, this also means applying the 'all or nothing' principle, because if the court does not see state action in the actions of a non-state entity violating the norms of the Basic Law, such action is not subject to any constitutional restrictions. This concept, as has already been mentioned, has a more procedural character and focuses on which entity may be subject to constitutional obligations and the procedural considerations that relate to these entities ${ }^{37}$. As R. Uitz points out, it is a sort of "filtering mechanism aiding courts in selecting cases where a party may be subjected to the commands of the Constitution's rights guaranties" 38 . Unlike in the case of indirect Drittwirkung, the publicising effect is total as a result of the jurisprudence strategy based on state action.

It is common knowledge that these jurisprudence strategies consist in the adoption of the binding force of constitutional norms in relations between private entities. In the case of entities that carry out tasks delegated by the State, there is a problem with clearly expressing their legal nature and thus also with determining their belonging to one of the sub-systems of law. The need for a comprehensive assessment of the circumstances surrounding each case translates into the very casuistic

Law, provided for such a possibility. It was applied in the jurisprudence of the Federal Labour Court during the presidency of H.C. Nipperdey (1954-1963). Nowadays, in the opinion of most constitutional law doctrines and jurisprudence, it is recognised that the vast majority of rights and freedoms are exercised only by the indirect third party effect.

35 Cf. e.g. S. Gardbaum, The "horizontal effect" of constitutional Rights, "Michigan Law Review", Vol. 102, December 2003, pp. 411-412.

36 Ibid., pp. 411-412.

37 Uitz, supra note 32 at p. 7.

38 Ibid., p. 6. 
character of this jurisprudence, which is particularly evident in the case of the concept of state action in the USA, where more detailed tests of state action are distinguished. It seems that the so-called 'public function' test ${ }^{39}$ is particularly appropriate for considering the issue of responsibility for the implementation of constitutional rights in a privatised reality. The starting point for the development of the concept of public function was the case of Marsh $v$. Alabama of $1946^{40}$. The US Supreme Court stated that the constitution applies to a privately administered city, so unwanted manifestations of religious freedom (distribution of leaflets) cannot be suppressed, as would be possible in a private home. Administering of the city is the exercise of a public function, traditionally reserved for the state. The Supreme Court stressed that "the more the owner opens their property for public use, the more the constitution applies". The test of the public function consists in examining whether the entity infringing the rights of other people performs 'traditional functions of the state'. The concept of state action has been used in many Supreme Court decisions ${ }^{41}$ and it should be noted that it evolved from its heyday in the 1940 s and 1950s to the 1970s when the conservative judge W. Renhquist narrowed down the already modest catalogue of areas considered to be state functions to 'functions that are traditionally and exclusively the prerogative of the state' and 'traditionally associated with sovereignty' ${ }^{42}$.

39 The second most widespread form of state action is based on the so-called nexus theory, in which it must be stated whether the state has been involved in the private activity that violates the rights of others. This involvement may take on different forms: during more detailed tests, the US Supreme Court examined, among other matters, whether there was 'close cooperation' or 'close enough connection' between the private and public entities, or whether the private activity was 'fairly attributable to the state', or whether the State encouraged a private body to act in a particular way.

40 The judgment of 7 January 1946, 326 U.S. 501 (1946).

${ }^{41}$ J.D. Niles, L.E. Tribble and J.N. Wimsatt, in their article from 2011, indicated that the problem of distinguishing between private and state action was considered more than 70 times in the judgments of the Supreme Court. See idem, Making Sense of State Action, “Santa Clara Law Review." Vol. 51, No 3, 2011, p. 886.

42 That line of jurisprudence was then used by the judges of the Supreme Court to declare that the following do not fulfill the test of such a public function: the supply of electricity by a private enterprise (Jackson v. Metropolitan Edison Co, 419 U.S. 345, 1974); settlement of disputes between a borrower and a lender (Flagg Bross Inc. v. Brooks, 436 U.S. 149, 1978); running of a school by a private entity, although maintained from public 


\section{Fraport JUdGMENT- GERMAN STATE ACTION}

An approach resembling the concept of a public function as a criterion for assessing whether a privatised entity may be subject to constitutional restrictions has also appeared in the jurisprudence of the German Federal Constitutional Court. In the judgment of 22 February 2011 in the Fraport case $^{43}$, it commented on the freedom of assembly and speech at Frankfurt Airport in the form of a mixed enterprise (a public limited company with a $52 \%$ State shareholding). In the case in question, the judges agreed with the applicant's assertion that Fraport S.A. acts as a legal entity to which the functions of state administration in the field of air transport have been delegated, and that the airport area is an element of infrastructure that provides public services. It stated that a private entity administering the airport cannot prohibit other private entities from exercising their constitutional rights at the airport, including the right to express opinions and organise demonstrations. If the state, in the performance of its public tasks, uses civil law organisational forms, these forms are subject to the Constitution as direct addressees of the rights. It is not only the state behind the enterprise that is bound by the constitution, but also the enterprise itself. In this case, however, the direct application of constitutional norms, in the light of the arguments of the Federal Constitutional Court, only resembled Drittwirkung. The decisive factor for the Federal Constitutional Court was not the legal form in which the entity operated, but who was the actual participant in legal relations. In this sense, the Fraport enterprise, organized as a public limited company,

funds (Rendell - Baker v. Kohn, 457 U.S. 830, 1982) or running of amateur sports by a private organisation, even if it has the exclusive right to represent American athletes (San Francisco Arts \& Athletics v. United States Olympic Committee, 483 U.S. 522, 1987).

${ }_{43} 1$ BvR 699/06, BVerfGE 128, 226. Among the publications on the judgment see e.g. J.Ph. Schaefer, Neues vom Strukturwandel der Öffentlichkeit, Gewährleistungsverwaltung nach dem Fraport-Urteil des Bundesverfassungsgerichts [News from the structural transformation of the public sphere, warranty management according to the Fraport judgment of the Federal Constitutional Court], "Der Staat”, Vol. 51, 2012, pp. 251-277; M. Goldhammer, Grundrechtsberechtigung und -verpflichtung gemischtwirtschaftlicher Unternehmen [Fundamental rights and obligations of economically mixed enterprises], JuS 2014, pp. 891-895. 
is 'private' only in a formal sense and not in a material sense. Thus, we are dealing here with the case of a relationship that is only seemingly of a private-law nature. It should be noted that the Federal Constitutional Court had already expressed a similar opinion in one of its judgments from $1989^{44}$. At that time, it took a position that was different from the German doctrine that granted mixed enterprises fundamental rights and proclaimed the need to protect the interests of their private shareholders.

Returning to the similarity of the arguments of the US and German courts, what is interesting in the Fraport judgment is that the Federal Constitutional Court considered that a comprehensive assessment of a private company should have been carried out in order to examine whether it was involved in the exercise of state action ${ }^{45}$. Although the criterion of control (Kriterium der Beherrschung), which assumes that in order to recognise the public character of a private entity, the State must have a majority shareholding in its ownership structure and thus hold more than $50 \%$ of shares in the company, was of decisive importance for the assumption of direct binding of Fraport with the fundamental right, it was also important that it conducted state activity ${ }^{46}$. Although the judgment does not explain in more detail (apart from indicating postal and telecommunications services) which types of activity belong to "state" activities, it should be assumed that they are those that had previously been the domain of the state. Another criterion referred to by the German court was the "public forum" criterion $^{47}$ developed in the jurisprudence of American and Canadian courts, which was already present in the judgment in the case of Marsh v. Alabama, i.e. the place where the owner must respect the exercise of constitutional rights and freedoms. The judgment of the Federal Constitutional Court means that

${ }^{44}$ Judgment of 16 May 1989, 1 BvR 705/88, NJW 1990, no 29, p. 1783.

45 In the case of Burton v. Wilmington Parking Authority the US Supreme Court stated: "(...) whether state action exists in a particular situation can be determined "only by sifting facts and weighing circumstances (...)".

46 The Federal Constitutional Court contrasted 'private activity with the participation of the state' with 'state activity with the participation of private entities'.

47 These are the judgments of the Supreme Court of Canada of 25 January 1991, Committee for the Commonweal th of Canada v. Canada (1991) 1S.C. R. 139 and the US Supreme Court of 25 June 1992, International Society for Krishna Consciousness <ISKCON> v. Lee, 505 U.S. 672 (1992). 
judges of German civil courts deciding in such cases in the future will not be able to restrict themselves to a simple distinction between the public and private spheres, but their assessment will have to refer to the concept of a public forum. The more a given space or object meets the definition of such a place, the weaker the associated property right will be. A broad interpretation of the concept of "public space" has enabled the Federal Constitutional Court, in its subsequent Bierdosen-Flashmob judgment a few years later, also related to the freedom of assembly, to include private space in a material sense within its framework of meaning. In it, the Federal Constitutional Court lifted the ban on demonstrations at Nibelung Square in Passau, which was owned by a "purely" private company, imposed by lower courts ${ }^{48}$.

Analysis of the explanations contained in the reasons behind the Fraport judgment leads to the conclusion that the interpretation scheme applied therein corresponds to the concept of state action. The judgment also provides a good illustration of the difficulties encountered by the public-law classification of mixed economic entities. The criteria adopted by the Federal Constitutional Court for this assessment raise a number of doubts and do not close the subject: one can imagine a different legal assessment of the nature of Fraport. If it is to be based on purely formal characteristics, one could conclude that we are dealing with direct Drittwirkung. However, even if we stick to the rhetoric applied by the Federal Constitutional Court, we cannot but notice that the consequence of the judgment was a direct obligation under the constitutional rights and freedoms of Fraport's private shareholders. Interestingly, in the reasons for the judgment, the Federal Constitutional Court acknowledges that the indirect effect of fundamental rights may be as intense as that of direct effect, especially if the private entity performs functions traditionally performed by the State.

On the margin of the judgments presented above, it is worth noting that the Polish Constitutional Tribunal has also made statements in

48 Interim Order of 18 July 2015, 1BvQ 25/15 in the Bierdosen-Flashmob case, in which the Federal Constitutional Court lifted the ban on demonstrations at Nibelung Square in Passau, which was owned by a 'purely' private company, imposed by lower courts, https://www.bundesverfassungsgericht.de/SharedDocs/Entscheidungen/DE/2015/07/, qk20150718_1bvq002515.html [last accessed 31.07.2019]. 
a similar vein on several occasions. It pointed to the existence of private entities which, owing to the performance of public tasks, are addressees of constitutional obligations resulting from regulations concerning the rights and freedoms of individuals. Thus, in its decision of 6 February 2001, it stated, in relation to public health care institutions, that entities which perform functions of authority are not the addressees of rights resulting from individual constitutional rights, but the addressees of obligations related to the exercise of the rights of people. It emphasized that the extension of the subjective scope of constitutional rights to the aforementioned entities would lead to the identification of entities that interfere with these rights with their carriers. However, the exercise of constitutional obligations related to the exercise of rights and freedoms of individuals has been imposed not only on public authorities, but also on other entities whose activities fall within the broadly understood scope of public authority ${ }^{49}$.

\section{CoRrective PUBLICISING}

The common denominator for the court statements presented above is the conviction that the state is not only a violator, but also a guarantor of rights and freedoms. If the legislative or executive authorities are unable to guarantee an adequate standard of protection of rights and freedoms or take actions leading to the reduction of that standard, the individual seeking protection of his or her rights may be interested in initiating court proceedings. Courts (constitutional or common, depending on the existing procedures) as public authorities have direct obligations by virtue of constitutional norms concerning rights and freedoms. The vertical applicability of these norms is, as we know, an unquestionable standard of contemporary constitutionalism, included in the provisions of basic laws ${ }^{50}$. The court's intervention is a reaction to the transfer of the tasks of the state to the private sphere - 'an escape of the state into private law'. As could be seen from the judgments mentioned above,

${ }^{49}$ Ref. no. Ts $148 / 00$.

${ }^{50}$ By way of example: Article 3 of the German Basic Law, the supremacy clause from Article VI of the US Constitution or Article 30 of the Polish Constitution of 1997. 
the extension of the binding force of constitutional rights and freedoms onto private relations is to counteract the reduction of citizens to the role of consumers, which is one of the consequences of privatisation. Horizontal application strengthens the position of the individual in relation to powerful private entities, such as companies, corporations, or other entities that gain strength by taking over public tasks, often assuming the role of a monopolist. It restores the balance distorted by the privatisation of state tasks and is therefore corrective in relation to the actions of other public authorities. It can be said that it performs contractual justice ${ }^{51}$. This type of argumentation which refers to the social dimension of law makes it possible, to a large extent, to legitimise the use of the indicated strategies in judicial decisions. However, it does not directly refer to this aspect of the strategy, which is connected with the problem of publicising the private relationship. As we have mentioned, the interference of the public factor in private autonomy also has that dimension. This publicisation is the most serious accusation filed against the expansion of the doctrine of third party effect. Covering a private entity with constitutional obligations is a restriction that constrains the freedom to act, i.e. the possibility of exercising one's own rights, e.g. the right to property. This in turn poses a threat to the functioning of liberal societies ${ }^{52}$.

\section{CONCLUSIONS}

It seems that the above accusation, when presented in genere, does not sufficiently take into account the variety of reasons for which the courts decide to use the horizontal application of constitutional norms. In the cases presented above, it was based on a prior assessment of the actual legal status of the entities in a given relationship. Only when it was stated that their activity fulfilled the test of a public function, did the horizontal application of constitutional rights or freedoms take place. In other words, I believe that the fact that formally private entities perform

51 J. Limbach, supra note 13 at p. 411.

${ }^{52}$ More about it see: M. Tushnet, The Relationship between Judicial Review of Legislation and the Interpretation of Non-Constitutional Law, with Reference to Third Party Effect, [in:] Sajo, Uitz, supra note 16 at p. 167 and 180. 
certain tasks or provide services that were previously the domain of the state, especially when the state does not offer a public alternative, justifies court intervention which 'makes the opportunities equal'. In the privatised reality, it seems possible and justified to resort to a strategy based on the doctrine of state action, the elements of which could also be seen in the Fraport case judgment. It makes it possible to assess whether the entity carrying out the tasks delegated by the State is still private or quasi-public. After all, a public entity does not enjoy private autonomy. In general, however, any doubts related to the threat to the private autonomy of a given quasi-public entity, or its private shareholders, are undoubtedly greater in the case of strategies based on the doctrine of state action. Indirect Drittwirkung, as G. Sommeregger points out, is, on the theoretical level, a construction that makes a horizontal effect of fundamental rights possible, and at the same time allows for the autonomy of private law from constitutional law ${ }^{53}$.

In any case, achieving a fair result of a formal private-law relationship, which balances the rights of both parties, is an extremely difficult task that requires a proportionate balance between the rights and obligations of both parties. In this context, the view expressed in the jurisprudence of the German Federal Constitutional Court, according to which the condition for giving the constitutional norm a horizontal effect is the occurrence of so-called structural inequality, is worth noting. The intensity of the horizontal effect should therefore depend on the degree of inequality between the parties to the legal relationship - the greater the need to protect personal freedom against extreme market power, economic or personal dependence, the greater the intensity ${ }^{54}$.

Since the horizontal application of constitutional rights and obligations follows the patterns developed by the courts, it is impossible to capture it in a coherent and comprehensive framework, let alone guarantee the predictability of decisions, as is the case with all other judicial concepts. The scale of the publicising effect depends, to a certain extent, on the discretionary decision of the court made each time. The less consistent and coherent the jurisprudence, the more justified the allegations of

${ }^{53}$ G. Sommeregger, supra note 25 at p. 43.

${ }^{54}$ Judgment of 13 October 1993, 1 BvR 567, 1044/89, BVerfGE 89, 214 Bürgschaftsverträge. 
arbitrariness ${ }^{55}$. Above all, these allegations seem to be serious in relation to the way in which the theses formulated by the US Supreme Court within the framework of the state action doctrine are applied to cases decided by federal appeal and district courts. According to some, a wide range of tests with liquid borders creates a 'state of complete confusion' in which private entities remain unaware of the criteria by which they will be subjected to restrictions arising from the Constitution ${ }^{56}$.

A separate issue to be considered is that aspect of judges' recourse to fundamental rights which takes the form of an allegation that the competences of the legislature are being taken over by the courts. After all, the former is democratically legitimised to draw a line between the private and public spheres ${ }^{57}$.

Finally, in the context of both the above and any other doubts present in the literature related to the horizontal application of constitutional norms, it would be worth considering the real scale of the use of the schemes discussed in the text. A firm assessment in this respect would, of course, require more extensive empirical research that would take into account all the differences related to the importance of jurisprudence in the USA and civil law countries. The opinions formulated in the academic literature illustrate the diverse classification of the phenomenon in question: from describing it as 'residual category'58 to recognising it as an element of the new constitutionalism ${ }^{59}$. First of all, we must remember that we are talking about the concept of jurisprudence, so its application, and thus the resulting publicisation of private law, is of an individual nature. In addition, in the case of the United States, in the last two decades the Supreme Court has seen a decrease in the number of cases referring to the category of state action. However, from the perspective of civil law countries, the horizontal application of constitutional rights and freedoms remains the domain of constitutional courts.

${ }^{55}$ For the criticism of US Supreme Court rulings see e.g E. Chemerinski, Rethinking State Action, "Northwestern University Law Review", 80/1985, pp. 503-557.

56 J.K. Brown, Less is More: Decluttering the State Action Doctrine, "Missouri Law Review", Vol. 73, Issue 2, 2008, p. 568.

57 Tushnet, supra note 29 at p. 168.

58 Ibid.

${ }^{59}$ Kühn, supra note 27 at p. 220. 